\title{
DE PARÍS A MADRID. MUJER Y FOTOGRAFÍA EN TIEMPOS DE AFRANCESAMIENTO CULTURAL (1850-1870) ${ }^{{ }^{*}}$
}

\author{
FROM PARIS TO MADRID. WOMAN AND PHOTOGRAPHY TIMES OF \\ CULTURAL FRENCHIFICATION (1850-1870)
}

\author{
DE PARIS A MADRID. TEMPOS DE MULHER E FOTOGRAFIA DA \\ FRENCHIFICAÇÃO CULTURAL (1850-1870)
}

\author{
STÉPHANY ONFRAY** \\ Universidad Complutense de Madrid \\ https://doi.org/10.46553/EHE.22.2.2020.p141-159
}

\begin{abstract}
Resumen
Si la labor de los fotógrafos franceses en la implantación del medio fotográfico en España ha sido más que reconocida, sus compatriotas fotógrafas, que a mediados del siglo XIX ya circulaban por el país, no tuvieron la misma suerte. El propósito de este artículo es múltiple. Por una parte, se propone reivindicar el rol de estas mujeres en la implantación de la fotografía en España, destacando su papel en la aceptación del oficio de "fotógrafa", algo que acabaría favoreciendo un libre acceso a la cámara para ellas. En segundo lugar, yendo un poco más allá, se señalará hasta qué punto la evolución formal del medio en España fue mediatizada por el destacable interés de las mujeres por la cultura francesa, y cómo este fenómeno propulsó la fotografía a la categoría de medio expresivo, suponiendo una verdadera revolución en la vida cotidiana del sexo femenino.
\end{abstract}

\section{Palabras clave}

Mujer y fotografía - Fotógrafas - Siglo XIX - Estudios de género - Afrancesamiento

\begin{abstract}
Although the work of French photographers establishing the medium Spain has been more than recognized, their women photographers' fellow, who were already circulating the country the mid-19th century, did not have the same fate. The purpose of this article is multiple. On the one hand, we want to vindicate the role of these women in the implantation of photography in Spain, highlighting their influence on the acceptation of the profession of "women photographer", something that would end up favouring them a free access to the camera. Secondly, we will point out how the formal evolution of the medium was mediated by the remarkable interest of French culture of Spanish women, and how this phenomenon propelled photography to the category of expressive medium, assuming a true revolution in the daily life of the female sex.
\end{abstract}

Keywords

Women and photography - Women photographer - XIX century - Gender study - Frenchification

\footnotetext{
* Fecha de recepción: 22/04/2020. Fecha de aceptación: 28/05/2020.

** Doctoranda en Historia del Arte en la Universidad Complutense de Madrid, ORCID n0000-0003-4187580X, stephany-o@live.fr.

${ }^{1}$ Este artículo es parte de la tesis doctoral que la autora está realizando actualmente sobre "El papel de la mujer en el desarrollo de la fotografía en Madrid en el s. XIX: el ejemplo de la Colección Castellano de la Biblioteca Nacional de España" en la Universidad Complutense de Madrid, bajo la dirección de Concha Casajús Quirós y Juan Miguel Sánchez Vigil. Le damos las gracias a Ana Velasco Molpeceres por su apoyo y consejo, así como a los correctores que revisaron este artículo.
} 


\section{Resumo}

Se o trabalho dos fotógrafos franceses na introdução do meio fotográfico na Espanha foi mais do que reconhecido, seus fotógrafos compatriotas, que já circulavam no país em meados do século XIX, não tiveram o mesmo destino. O objetivo deste artigo é múltiplo. Por um lado, propõe-se reivindicar o papel dessas mulheres na implantação da fotografia na Espanha, destacando seu papel na aceitação da profissão de "fotógrafo", algo que acabaria por favorecer o livre acesso à câmera para elas. Em segundo lugar, indo um pouco mais adiante, será apontado em que medida a evolução formal do meio na Espanha foi mediada pelo notável interesse das mulheres na cultura francesa e como esse fenômeno levou a fotografia à categoria de meio expressivo, assumindo uma verdadeira revolução na vida cotidiana do sexo feminino.

\section{Palavras-chave}

Mulheres e fotografia - Mulheres fotógrafas - Século XIX - Estudo de gênero - Frenchification

\section{Introducción}

La historiografía de la fotografía española siempre ha estado atenta a la influencia de sus vecinos franceses en la implantación del medio en el suelo nacional. El caso de Jean Laurent en Madrid no es el único, pero sí el más emblemático. Desgraciadamente sus compatriotas fotógrafas, que a mediados del siglo XIX ya circulaban por el país, algunas viajando de ciudad en ciudad, no tuvieron la misma suerte. ${ }^{2}$

Aun así, a la luz de nuevos trabajos que sitúan en el punto de mira el sesgo patriarcal que pudo llegar a tener la historia de la fotografía, poco a poco se va entendiendo cada vez mejor el rol que tuvo la mujer en el desarrollo de este nuevo lenguaje visual en España. ${ }^{3}$ El presente artículo, cuya metodología está inspirada por estos planteamientos, ${ }^{4}$ tiene varios propósitos.

Por una parte, se propone explicar el papel de las operadoras francesas que, junto a sus compatriotas masculinos, fueron partícipes del desarrollo de la técnica fotográfica en España. Se destacará el ascendiente que tuvieron las fotógrafas sobre la paulatina feminización del oficio, así como las consecuencias de este proceso: el acceso libre e incuestionable de las mujeres al estudio fotográfico, pero también a la práctica profesional o amateur.

En segundo lugar, centrándose en los años dorados de la carte de visite en España, se tratará de señalar cómo la representación fotográfica de la mujer en los estudios fue en todo punto mediatizada por el afrancesamiento cultural que, desde el siglo XVIII, se había

\footnotetext{
2 Paulatinamente, se van remediando estas deficiencias. A modo de breve estado de la cuestión podemos mencionar la persistente labor de María de los Santos García Felguera: GARCÍA FELGUERA, 2005-2006, pp. 307-335; 2007, pp. 169-184; 2008, pp. 1-5; 2014, pp. 451-476 y 2017, pp. 51-58. Aprovecho para agradecerle por haberme facilitado algunos de sus escritos, necesarios para la realización de este artículo. También son de interés las investigaciones de Carmen Agustín Lacruz, y Sandra Tomás Esteban, en las que se mencionan algunas de las fotógrafas que nos interesan aquí: AGUSTÍN LACRUZ y TOMÁS ESTEBAN, 2018, pp. 621-658.

${ }^{3}$ Tuvimos la ocasión de investigar este tema en: ONFRAY, 2018, pp. 13-37 y 2019, pp. 17-40.

${ }^{4}$ Los estudios de Patrizia Di Bello, que abordan la historia de la fotografía desde el género, reivindicando el estudio de prácticas que hasta ahora no habían sido valoradas por ser consideradas como "femeninas" (como la concepción de álbumes fotográficos, entre otras) resultan especialmente importantes para nuestro planteamiento: DI BELLO, 2007 y 2015, pp. 64-107. También resulta de gran interés la tesis doctoral defendida en 2014 por Ya-Lei Yen, en la que se incluye un capítulo sobre el uso de la fotografía como medio de comunicación (mediante su representación) por las mujeres. Véase YEN, 2014, pp. 116-170. Por fin, y más recientemente, Nicole Hudgins ha estudiado los mecanismos que llevaron a diferenciar ciertos usos fotográficos según las identidades de género, y ello desde los primeros años del medio: HUDGINS, 2020.
} 
instalado con mayor o menor resistencia en el país. ${ }^{5} \mathrm{El}$ propio origen del daguerrotipo o de la tarjeta de visita justificaría este hecho sin demasiado problema; sin embargo, yendo un poco más lejos, se procurará demostrar cómo la fotografía llegó a materializar la inclinación de las españolas por las formas galas y, en contrapartida, también presenció la expansión de un cierto afán de defensa de lo castizo, dentro del proceso de construcción nacional. Este fenómeno, propio de la cimentación de las identidades en la edad contemporánea, y muy relacionado con cuestiones de género, propulsó la fotografía a la categoría de medio de expresión ideológico y visual, algo que acabará por tener una gran influencia sobre la vida cotidiana de las mujeres.

Para cumplir con estos objetivos, se hará evidentemente uso de material fotográfico, asociándolo con varias metodologías, entre las cuales destacaría el análisis formal y sociológico de la problemática. Asimismo, también se aprovechará la especial influencia que pudo llegar a tener la prensa sobre la sociedad de su tiempo. De este modo, nos interesaremos por los diarios pero también por la prensa femenina -y los figurines que incluía en numerosas ocasiones- puesto que llegaron a ser tanto testigos como promotores de ciertos hábitos relacionados con la relación mujer/fotografía y el afrancesamiento cultural.

\section{La difusión de la palabra}

Cuando en 1839 el gobierno francés, representado por François Arago (1786-1853) adquirió los derechos de distribución del daguerrotipo, a cambio de una pensión a favor de sus creadores y con el fin de ponerlos graciosamente a disposición de la ciudadanía, ${ }^{6}$ entendía muy bien las consecuencias políticas, ideológicas y culturales de su aparente generosidad. ${ }^{7}$ Suponía la asimilación del Estado galo a la idea de modernidad, inherente al descubrimiento fotográfico ${ }^{8}$ una noción que no tardó en exportarse, pues, ya a mediados de la década de 1840, numerosos daguerrotipistas invadieron España, considerándola como una tierra fértil y virgen. ${ }^{9}$

Si bien se ha resaltado la presencia de numerosas fotógrafas autóctonas, lo cierto es que una parte destacable de las pioneras de la fotografía en España tenía orígenes franceses, ${ }^{10}$ y usaban a modo de reclamo el título de "Madame" o "Madama",11 especificando en general su fama parisina. ${ }^{12}$ Así, fue el caso de Madama Fritz, ${ }^{13}$ fotógrafa

\footnotetext{
${ }^{5}$ No se trata aquí de relatar la ambigüedad de las relaciones políticas entre España y Francia entre los siglos XVIII y XIX puesto que este asunto ya ha sido el tema de numerosos estudios que, paulatinamente, permiten la elaboración de una historia cada vez menos estereotipada del fenómeno de "afrancesamiento", cuyos frutos deben considerarse en cuantiosos campos de investigación. Véase: ARTOLA GALLEGO, 2008 y MERCADER RIBA, 1971. Queremos destacar el estudio de Elisa Martín-Valdepeñas cuyo planteamiento permite destacar el papel de las mujeres en el desarrollo del afrancesamiento en España: MARTÍNVALDEPEÑAS, 2010, pp. 79-108.

${ }^{6}$ La pensión se atribuyó en 1839 a Louis Daguerre (1787-1851) y a los herederos de Joseph Nicéphore Niépce (1765-1833). MCCAULEY, 1997, p. 9.

${ }^{7}$ Más aún si se considera la rareza de este tipo de rentas. Ibídem.

${ }^{8}$ También suponía una victoria simbólica sobre Inglaterra, ninguneando las reclamaciones de autoría de Henri Fox Talbot. Ibídem, pp. 2 y 13.

${ }^{9}$ Fue también el caso de calotipistas, como bien lo recoge el catálogo de exposición: VV.AA., 2015.

${ }^{10}$ GARCÍA FELGUERA, op. cit., 2005-2006, p. 308.

11 Algunas fotógrafas españolas también siguieron este modelo, seguramente atraídas por el éxito y la atracción hacia lo francés GARCÍA FELGUERA, op. cit., 2014, p. 459.

12 Así lo hizo, entre otras, Madama Valpery, "muy acreditada en París" (El Heraldo, 12/08/1842, p. 4, citado en: GARCÍA FELGUERA, op. cit., 2017, p. 59.

${ }^{13}$ La figura de Madame Fritz ha atraído la atención de varios investigadores y ha sido estudiada por: HUGUET CHANZÁ, 1990; GARÓFANO SÁNCHEZ, 1993; CANCER MATINERO, 2006; GÓNZALEZ
} 
e iluminadora ambulante procedente del norte de Francia, ${ }^{14}$ que trabajó en diversas ciudades españolas anunciando proezas tecnológicas; ${ }^{15}$ de Madama Valpery, ${ }^{16}$ que en 1842 se anunciaba junto a Mr. Sardin $;{ }^{17}$ o de la "artista de París" Madama Senges. ${ }^{18}$ El ejemplo de Catherine Esperon (1828-1912), originaria del sur de Francia, es especialmente reputado. Tras casarse con el italiano Antonio Ludovisi, se instalaría en Valencia, abriendo la pareja un estudio de fotografía de 1864 a $1875 .{ }^{19}$ Otra fotógrafa francesa destacable fue Anne (Anaïs) Tiffon Cassan (1831-1912) que conformaría hacia 1852-1853 en Barcelona, ${ }^{20}$ junto con su esposo Antonio Fernández Soriano (1827-1916), una de las dinastías fotográficas más importantes y reconocidas: "M. Fernando y Anaïs Napoleon".

Sin embargo, la labor de estas mujeres no se limitó a la producción y venta de retratos fotográficos. Algunas de ellas se comprometieron, solas o junto a sus esposos, a difundir el invento de Daguerre mediante la enseñanza de la técnica, algo que no tendría tanto interés si ciertos anuncios no estuviesen dirigidos a "las señoras y señoritas". ${ }^{21}$ Así, en 1849, Madama Senges promocionaba en Madrid un "curso de enseñanza de daguerrotipo en 15 lecciones a precios moderados", destinado exclusivamente a mujeres, afirmando públicamente el derecho de las mismas a deleitarse con los beneficios emancipadores otorgados por el medio.

Es factible suponer que la influencia de este modelo de mujeres daguerrotipistas, cuya actividad presuponía la aceptación del disfrute femenino de la fotografía, ${ }^{22}$ posibilitó una cierta desenvoltura acerca del acceso de las mujeres al medio. A partir de mediados de los años 1850, este patrón empezó a reflejarse en varios medios de la época. Resulta especialmente llamativa la presencia de cuantiosas referencias a la fotografía en la prensa

PÉREZ, 2007; GARCÍA FELGUERA, op. cit., 2014; MARTÍ BAIGET, 08/06/2018; VEGA DE LA ROSA, 2017 y ONFRAY, op. cit., 2018.

${ }^{14}$ En 1843, Madama Fritz anunciaba "retratos con colores y de varios tamaños". Véase: El Imparcial, 10/05/1843, p. 4 citado en: MARTí BAIGET, op. cit., 08/06/2018. Asimismo, según una información encontrada por Jep Martí Baiget, Madama Fritz sería en realidad Suiza (MARTí BAIGET, 2020, en prensa), lo que nos deja pensar que la fotógrafa aprovechó su conocimiento de la lengua francesa para alentar su negocio asociándose al país de Daguerre. GARCÍA FELGUERA, 2021, en prensa. Agradecemos a María de los Santos García Felguera por comunicarnos este dato.

${ }^{15}$ Madama Fritz, que se enorgullecía de poder realizar retratos disponibles "en el corto tiempo de 8 a 12 segundos" ("Retrato al daguerrotipo", El Phoenix, 13/04/1845, p. 150 citado en: VEGA DE LA ROSA, op. cit., p. 114. pasó por Córdoba, Madrid, Barcelona, Cádiz o Valencia. El itinerario de la fotógrafa ambulante, que posteriormente se casaría con el fotógrafo francés Mr. Durrieu (CANCER MATINERO, op. cit., p. 34) y se instalaría en Portugal, fue más que detallado en: GARCÍA FELGUERA, op. cit., 2014, p. 463.

${ }^{16}$ GARCÍA FELGUERA, op. cit., 2017, p. 59 y VEGA DE LA ROSA, op. cit., p. 113.

${ }^{17}$ El Heraldo, 12/08/1842, p. 4, citado en: GARCÍA FELGUERA, op. cit., 2017, p. 59.

${ }^{18}$ VEGA DE LA ROSA, op. cit., p. 122 y ONFRAY, op. cit., 2019, p. 24.

${ }^{19}$ Hasta 1875, fecha de fallecimiento de Antonio Ludovisi, se consideró como uno de los estudios más importantes de Valencia: GARCÍA FELGUERA, op. cit., 2014, p. 469. Un autorretrato de Catherine Esperon se conserva en la Biblioteca Valenciana y está reproducido en: ibídem, p. 470.

${ }^{20}$ Ibídem, p. 463.

21 "Madama Senges", El Heraldo, 08/11/1849, p.4, citado en: VEGA DE LA ROSA, op. cit., p. 122.

${ }^{22}$ Daguerre describía la práctica del daguerrotipo como un "pequeño trabajo" que podría gustarles mucho a las mujeres", refiriéndose seguramente a la práctica amateur DAGUERRE, 1838, citado en: GALIFOT, 2015 , p. 41. Aun así, el proceso de aceptación del oficio de fotógrafa en Francia no fue tan sencillo o rápido (Ibídem) y el sueldo de las empleadas de estudio en París era más de dos veces inferior al sueldo de los hombres (MCCAULEY, 1994, p. 39). Ciertas propietarias de estudios incluso sufrieron estafas por parte de sus empleados (Ibídem, p. 38). Quizá sería interesante relacionar esta falta de reconocimiento con el crecimiento de la práctica ambulante para las mujeres, ofreciendo ésta una libertad de acción difícilmente imaginable en un estudio. Es más, Thomas Galifot relaciona el oficio de fotógrafas con mujeres "solteras, separadas o a punto de divorciarse": GALIFOT, 2017, pp. 1-5. 
femenina española, y en particular en los figurines que contenía, ${ }^{23}$ cuya gran mayoría eran reproducciones de grabados franceses. ${ }^{24}$ Entre otros, la importación de dibujos permitió la publicación en el Álbum de señoritas y Correo de la moda, ya en 1855, de imágenes como el dibujo de Jules David, originalmente editado en Le Moniteur de la Mode, y en el que se encontraban dos mujeres en un estudio fotográfico (Figura 1). ${ }^{25}$

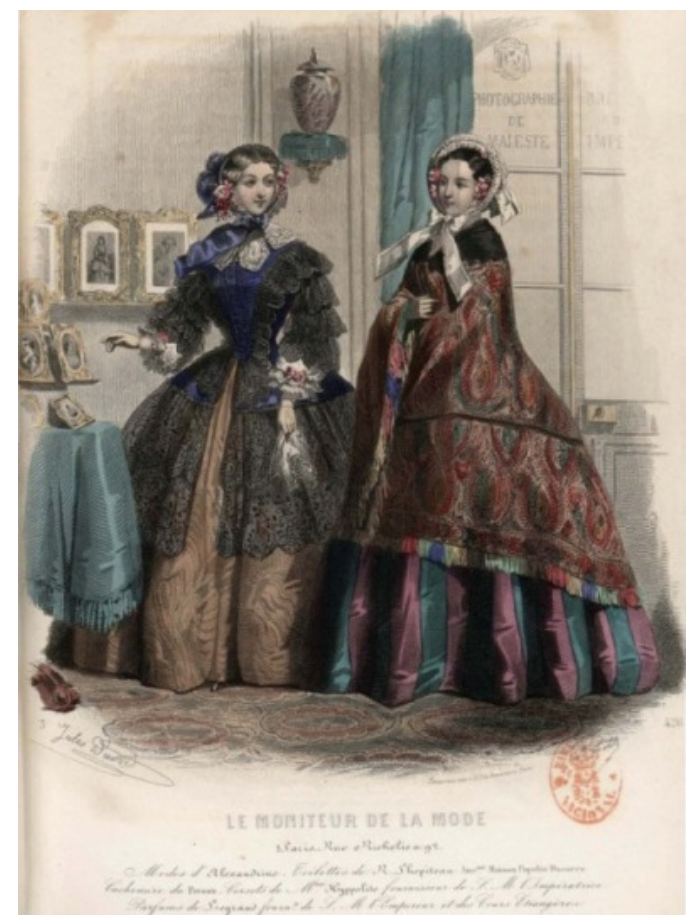

Figura 1: Jules David, Figurín de moda: dos mujeres en un estudio fotográfico, publicado en Álbum de señoritas y Correo de la moda, 16/04/1855, p. 9, Biblioteca Nacional de España. ${ }^{26}$ Publicado originalmente en Le Moniteur de la Mode, 1er número de abril de 1855, p. 2 bis).

Incluso se ha considerado la posibilidad de que éstas se hallaran en la galería de Eugène André Adolphe Disdéri (1819-1889), el mismísimo inventor del proceso de la carte de visite, pues el fotógrafo abrió su estudio en París durante el verano de 1854, antes

\footnotetext{
${ }^{23}$ Los figurines, además, eran uno de los principales atractivos de las revistas de moda del XIX. Véase: VELASCO MOLPECERES, 2016, p.161. La fotografía, por otra parte, sigue siendo primordial en la prensa femenina, en la que prima la imagen y los aspectos estéticos sobre otros temas, incluso en la actualidad. Véase: VELASCO MOLPECERES, 2019, pp. 153-185.

${ }^{24}$ Imprimiéndose de forma descuidada, en algunas ocasiones, el nombre de la revista española encima del periódico francés. Véase: VELASCO MOLPECERES, op. cit., 2016, p. 161. En un anterior trabajo, analizamos la presencia de referencias a la fotografía en un conjunto de 2.684 revistas femeninas publicadas entre 1839 y 1880, y cuyos ejemplares se conservan actualmente en la BNE: El Correo de la Moda (18511852), Álbum de Señoritas y Correo de la Moda (1853-1864), La Moda Elegante (1861-1923), La Educanda (1861-1865), La Violeta (1862-1866), El Correo de la Moda (1865-1880), La Guirnalda (18671880), y La Ilustración de la Mujer (1875-1876). Tras el análisis sistemático de los 2.684 ejemplares, se han hallado: 36 láminas con uno o varios álbumes fotográficos abiertos y 13 posibles álbumes cerrados; 17 ilustraciones de objetos manufacturados a partir de retratos fotográficos, 14 láminas que incluyen al menos una tarjeta de visita; 12 láminas con marcos, medallones o cajitas con fotografía, 6 tarjeteros, 1 visor de fotografías estereoscópicas, 1 imagen representando la sala de espera de un estudio fotográfico parisino, y 1 mujer fotografiando en un salón. En total, se trata de más de 100 referencias a la fotografía, siendo $L a$ Moda Elegante $(69,30 \%)$ y El Correo de la Moda $(21,78 \%)$ los mayores representantes del fenómeno.

${ }^{25}$ Le Moniteur de la Mode, número 1 de abril de 1855, p. 2 bis.

${ }^{26}$ En adelante BNE.
} 
de inventar el sistema que patentó en noviembre del mismo año. ${ }^{27}$ En ese momento, aunque el nuevo formato todavía no había alcanzado el éxito que se le conoce, el estudio de Disdéri ya tenía una cierta fama por ser, según el teórico y crítico Ernest Lacan (18291879), el más grande de la capital francesa, ${ }^{28}$ y por haber instalado un salón especialmente destinado al bello sexo. ${ }^{29}$ Las inscripciones presentes en el grabado de David ("Photographie de Majestê" y lo que adivinamos como "Brevet de l'Empereur") 30 no hacen más que reforzar esta sospecha. ${ }^{31}$ Pero se trate del estudio Disdéri o no, el grabado no deja de ser una incontestable y temprana demostración de la consideración de la fotografía como una actividad recreativa más para ellas. ${ }^{32}$

Otro de los motivos recurrentemente incluidos en los figurines fueron las referencias a álbumes o carte de visite. A modo de ejemplo, se pueden citar varias muestras de ello, localizadas en periódicos femeninos como La Violeta o La Moda Elegante. ${ }^{33}$ Estas publicaciones también solían adquirir los derechos de reproducción de grabados franceses como los de Anaïs Toudouze (1822-1899) o de sus hermanas Héloïse Leloir (1820-1873) y Laure Noël (1827-1878), tres de las máximas ilustradoras de moda de su tiempo (Figura 2). ${ }^{34}$

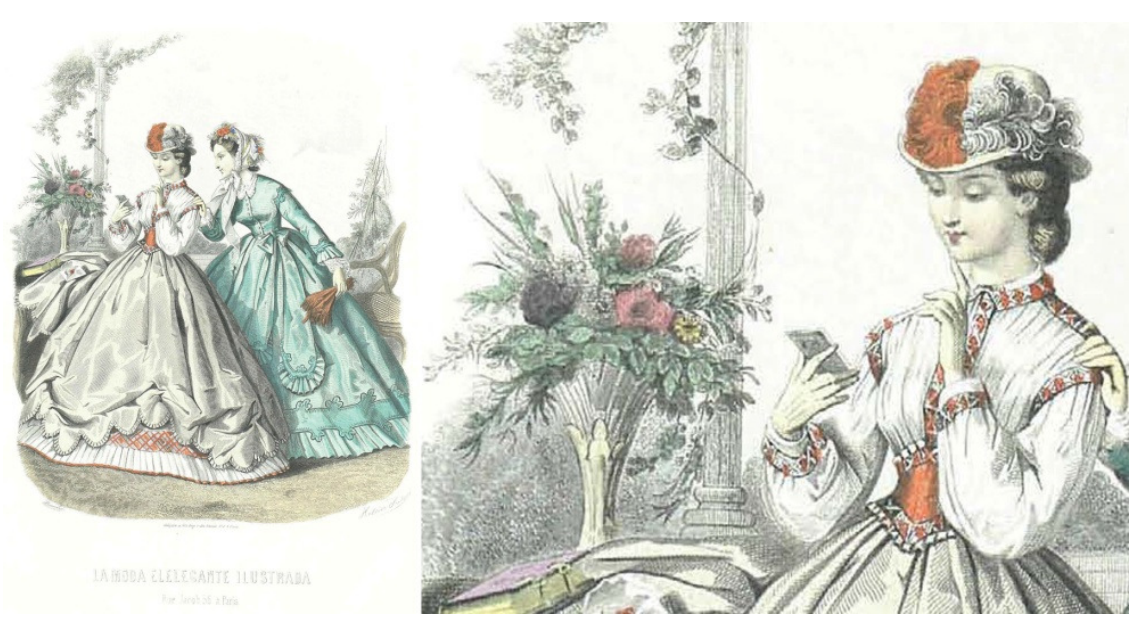

Figura 2: Héloïse Leloir, Figurín de moda: dos mujeres observando una tarjeta de visita recibida por correo (con detalle), La Moda Elegante, 31/07/1864, p. 9, BNE. Publicado originalmente en La Mode Illustrée, 5/06/1864.

No obstante, las revistas femeninas no solamente ofrecieron una visión de la mujer como espectadora/consumidora de la fotografía sino que incentivaban, a veces debido a

\footnotetext{
${ }^{27}$ MINISTERE DE L'AGRICULTURE Y DU COMMERCE, 1854, p. 418.

${ }^{28}$ MCCAULEY, 1985, p. 23.

${ }^{29}$ Ibídem.

30 "Fotografía de su Majestad" y "Patente del Emperador".

${ }^{31}$ Aunque Disdéri no haya pasado a ser fotógrafo oficial de Napoléon hasta 1859, se sabe que en 1856 varios miembros de la familia real habían pisado su estudio MCCAULEY, ibídem, p. 45 y MCCAULEY, op. cit, 1994, p. 301.

${ }^{32}$ El propósito de nuestra tesis doctoral es demostrar que la fotografía era algo más que una actividad recreativa para las mujeres.

33 Véase entre muchos otros ejemplos: Héloïse Leloir, La Moda Elegante, 31/07/1864, p. 9; Anaïs Toudouze, La Violeta, 13/03/1864, p. 17 o Anaïs Toudouze, La Violeta, 23/07/1865, p. 17.

${ }^{34}$ Se encuentran en particular numerosos dibujos firmados por Héloïse Leloir, Anaïs Toudouze y Laure Noël, hijas del pintor francés Alexandre Colin (1798-1875) y de la pintora Marie Josèphe Juhel (17961837), que dedicaron su vida a la ilustración de moda, revolucionando el género. Véase: HIGONNET, 2018 [1991], p. 308. Las tres hermanas Colin prestaban una gran importancia a la puesta en escena, ofreciendo una gran cantidad de detalles y situaciones. Asimismo, portaron una especial atención al medio fotográfico, reiterando las menciones al mismo.
} 
ciertos intereses comerciales, el desarrollo de la práctica amateur $^{35}$. De esta manera, $L a$ Moda Elegante publicaba en 1866 un grabado de Anaïs Toudouze, ${ }^{36}$ originalmente difundido en La Mode Illustrée en $1866,{ }^{37}$ y cuyo tema se centraba en una sesión de fotografía entre damas. La ilustración encubría en realidad un reclamo para el "Aparato Dubroni", ${ }^{38}$ una cámara revolucionaria procedente de Francia, estando La Moda Elegante encargada de su distribución en el territorio español (Figura 3). ${ }^{39}$

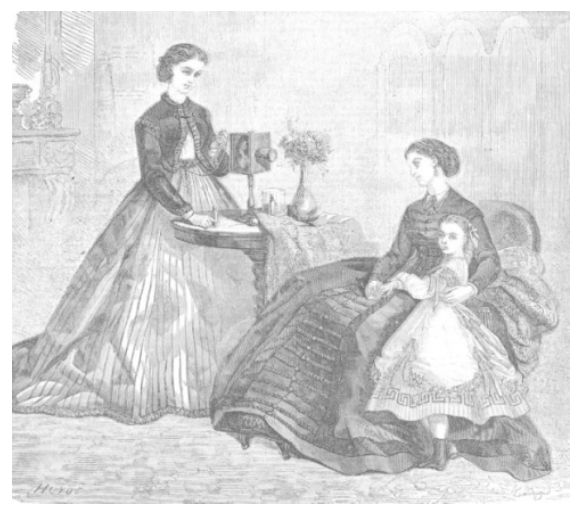

Figura 3: Anaïs Toudouze (c.1864) Figurín de moda: Ilustración para la cámara Dubroni, publicado en La Moda Elegante, 11/03/1866, pp. 7-8, BNE. ${ }^{40}$ Publicado originalmente en La Mode Illustrée. Journal de la famille, 01/01/1866, p. 5.

La estrategia publicitaria de la marca Dubroni en España fue muy representativa del considerable interés comercial que suscitaban las mujeres a la industria fotográfica, y de cómo algunos empresarios franceses consideraron a España como terreno idóneo para multiplicar sus ventas. ${ }^{41}$ Este anuncio se orientaba exclusivamente al sexo femenino con

\footnotetext{
${ }^{35}$ Las revistas femeninas son una fuente inagotable para entender el gran interés que tenían las mujeres hacia la cultura visual de su tiempo. Asimismo, algunas colaboradoras o directoras de dichas publicaciones, como Pilar Sinués de Marco (1835-1893) o Ángela Grassi (1823-1883), otorgaban públicamente una gran importancia a la literatura, o incluso a la escritura. El sentimiento de "hermandad" potenciado en revistas como El Ángel del Hogar o La Violeta favoreció sin duda el desarrollo intelectual y cultural de sus lectoras. Véase: BLANCO, 2001 y VELASCO MOLPECERES, 2018, pp. 97-114.

${ }^{36}$ La Moda Elegante, 11/03/1866, pp. 7-8, BNE, citado en: VEGA DE LA ROSA, op. cit., pp. 704-705.

${ }^{37}$ Thomas Galifot señala, siguiendo la catalogación del Münchner Stadtmuseum de Munich, que el grabado hubiese sido publicado en 1864 (GALIFOT, op. cit., 2015, p. 41). Sin embargo, al no haber podido localizarlo en los números de La Mode illustrée del año 1864 y, tras ponernos en contacto con el Münchner Stadtmuseum, hemos sabido que éste solamente conservaba una hoja suelta y no el periódico completo. Consultando los números de La Mode illustrée publicados entre 1861 y 1866, se pudo encontrar la fecha de publicación original: el 01/01/1866, es decir solamente dos meses antes de la difusión de su reproducción en España. Véase: La Mode illustrée, 01/01/1866, p. 5. Le damos las gracias a Ulrich Pohlmann (Jefe de la colección de fotografía del Münchner Stadtmuseum de Munich) y a Thomas Galifot (Jefe de las colecciones de fotografía del Musée d'Orsay) por su amabilidad y por la información facilitada.

${ }^{38}$ Creado por Jules Bourdin (1832-1893) este aparato, cuyo sistema basado en la asociación de la técnica del colodión y de un laboratorio compacto y simplificado (FOUCHIER, 1977, pp. 102-103) aliviaba considerablemente la dificultad técnica de la fotografía (HANNAVY, 2008, pp. 195-196).

${ }^{39}$ La Moda Elegante consagra una página completa a esta nueva "fotografía Faltriquera al uso de todos [...] para operar sin laboratorio al aire libre, en una sala o de viaje" (La Moda Elegante, 06/05/1866, p. 8), vendida por 300 reales (700 para la versión de viaje) por la propia revista, que afirma hacerse cargo de la distribución del objeto en Madrid y Cádiz. Para más información sobre la campaña de comunicación puesta en marcha por Dubroni en España, véase: ONFRAY, op. cit., 2019, p. 26.

${ }^{40}$ VEGA DE LA ROSA, op. cit., pp. 704-705.

${ }^{41}$ La campaña de difusión de la cámara Dubroni alcanzó muy rápidamente a la península puesto que, en septiembre de 1865, ya se podía encontrar el sello de la marca en los periódicos españoles. Véase La Iberia, 01/09/1865, p. 4. A partir de noviembre del mismo año se modifica el anuncio, en el que se incluye a la
} 
un dispositivo "preparado de manera que se pueden [sic] obtener fotografías lo mismo al aire libre que en un salón, sin mancharse los dedos". ${ }^{42}$ Gracias a la simplificación de la técnica que propiciaba el aparato Dubroni, la fotografía se acercó paulatinamente al ámbito privado, entonces controlado por las mujeres. Años antes de la aparición de la marca Kodak, el Dubroni hizo de puente entre deseo y realidad para algunas aficionadas. ${ }^{43}$

\section{La difusión des modes}

Una vez reconocido el papel de las mujeres -fotógrafas profesionales o no- en la democratización de la técnica fotográfica y de su difusión en España, queda por destacar la contribución de las mismas a la evolución formal del medio que, a su vez, está muy unida al afrancesamiento cultural, o a su rechazo. El temprano interés que la nobleza y la alta burguesía prestaron a la fotografía, y las fuertes relaciones que estas clases mantenían con la élite parisina, reunieron las condiciones idóneas para la propagación de modes que no tardarían en generalizarse en los estudios madrileños.

Una vez más, la consulta de la prensa femenina es crucial, pues las estrategias de representación elaboradas por las mujeres -siempre con el fin de aprovechar todas las cualidades comunicativas del medio- ${ }^{44}$ fueron de nuevo influenciadas por los figurines de moda procedentes de Francia. ${ }^{45} \mathrm{El}$ inmenso interés del sexo femenino por asimilar posados, costumbres o indumentarias previamente difundidas en estas publicaciones se vio cada vez más reflejado en los estudios fotográficos, ${ }^{46}$ creándose normas de representación femeninas que no tardarían en difundirse. En este sentido, pueden destacarse imágenes donde las retratadas aparecen en diversas actitudes: apoyándose sobre una silla balanceada (Figura 4); de espaldas -deseosas de enseñar la parte trasera de su vestido; ${ }^{47} \mathrm{o}$ bien posando con un librito, un álbum de fotografías ${ }^{48}$, una cesta de flores, cosiendo, ${ }^{49}$ leyendo una carta, ${ }^{50}$ o tocando algún instrumento de música. ${ }^{51}$ También se

Casa Chavarri, situada en la calle de Fuencarral 30, como primer punto de venta Dubroni en Madrid ( $L a$ Discusión, 04/11/1865, p. 4).

${ }^{42}$ Revista de Bellas Artes, 27/10/1866, p. 6.

${ }^{43}$ Sin embargo, sigue siendo difícil conocer el alcance de las ventas de los aparatos Dubroni en España. Evidentemente, se trataba de una cámara reservada a la élite, lo que limitó necesariamente su difusión. Desde luego, queda excluido pensar que las cámaras Dubroni tuviesen un éxito similar al que tuvieron las cámaras de Kodak a finales de los años 1880 , pero sí se puede suponer que tenían suficiente potencial para que Bourdin planteará una publicidad internacional.

${ }^{44}$ ONFRAY, op. cit., 2019, pp. 29-30.

${ }^{45}$ El acceso de las españolas a la prensa femenina francesa ya se veía asegurado desde por lo menos 1847 , gracias a la posibilidad de suscribirse a revistas como Les Modes Parisiennes, considerada por la opinión pública como “el espejo y el guía de las notabilidades elegantes”. Véase: El Eco del comercio, 26/10/1847, p. 4.

${ }^{46}$ Este fenómeno se invertiría a partir de los años 1870, quedando cada vez más patente la influencia del retrato fotográfico para la elaboración de los dibujos.

47 Véase: “Atribuido a José Martínez Sánchez, Retrato de mujer de espalda, ca. 1860, BNE, fondo fotográfico de la Colección Castellano (en adelante Col. Castellano), tomo 16, 17-LF/61-323.4" y " $L a$ Moda Elegante, 13/12/1863, p. 5". La propia Eugenia de Montijo empleó esta pose en uno de sus retratos fotográficos. Véase: MCCAULEY, op. cit., 1985, p. 67.

${ }^{48}$ Un ejemplo de ello ha sido publicado en: ONFRAY, op. cit., 2019, p. 28.

${ }^{49}$ Véase: “Atribuido a José Martínez Sánchez, Retrato de mujer cosiendo, ca. 1860, BNE, fondo fotográfico de la Col. Castellano, tomo 2, 17-LF/47-72v.8” y "La Moda Elegante, 05/07/1863, p. 9".

50 “Anónimo, Retrato de mujer leyendo una carta, ca. 1860, BNE, fondo fotográfico de la Col. Castellano, tomo 4, 17-LF/49-24.7” y “Álbum de Señoritas y Correo de la Moda, 16/12/1856, p. 9”.

${ }^{51}$ Véase: “Anónimo, Retrato de dos mujeres en torno a un piano, ca. 1860, BNE, fondo fotográfico de la Col. Castellano, tomo 7, 17-LF/52-27v.7” y “La Violeta, 20/03/1864, p. 17”. 
hallan retratos con disfraces (recuerdos del último baile de sociedad), ${ }^{52}$ o simplemente con uno de los dos accesorios que no podían faltar a una dama: el pañuelo y el abanico. ${ }^{53}$

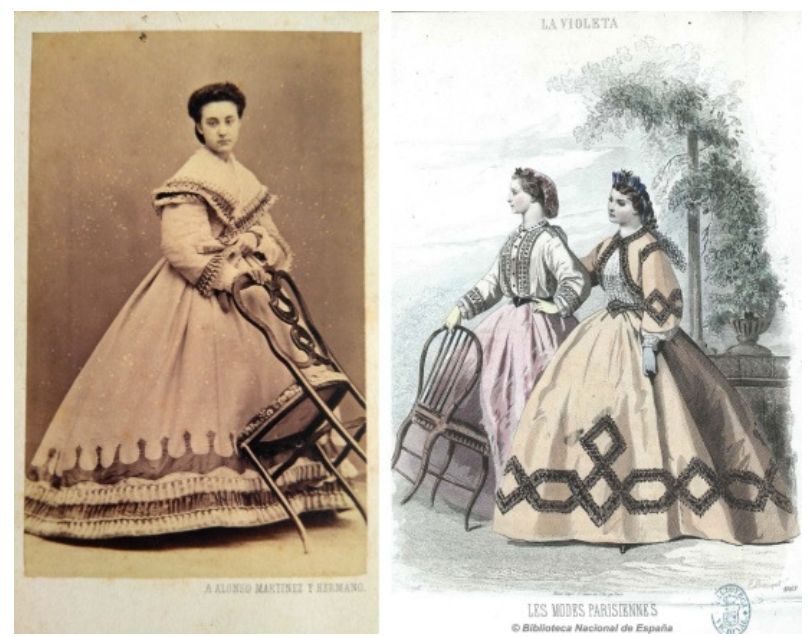

Figura 4: Comparación entre "François Claudius Compte-Calix, Figurín de moda, La Violeta, 0208-1863, p.9 (originalmente publicado en Les Modes Parisiennes)" y "Atribuido a Ángel Alonso

Martínez, Retrato de una mujer anónima balanceando una silla, colección de la autora”.

Otro fenómeno que pudo llegar a tener alguna influencia sobre la difusión de ciertas formas de representación afrancesadas en los estudios fue la llegada, en la década de 1850-1860, de varios fotógrafos galos que, ante el éxito de la carte de visite en España, decidieron abrir, por más o menos tiempo, sus propios establecimientos en la capital. Aunque numerosas tiendas madrileñas distribuían fotografías francesas, ${ }^{54}$ los escaparates de estos fotógrafos forasteros pudieron llegar a suponer un soplo de aire fresco en la ciudad. En este sentido, nos interesa particularmente la presencia de Ernst Mayer ${ }^{55}$ (del famoso estudio parisino Mayer \& Pierson, en el que posaba Virginia Oldoini (18371899), condesa de Castiglione), que en 1864 trabajó en la calle Hortaleza $130{ }^{56}$ Resulta llamativo el hecho de que, tras anunciar una exposición de sus obras más notables en un escaparate de la calle Alcalá, ${ }^{57}$ esta muestra acabe siendo robada en menos de dos meses. ${ }^{58}$ Aunque sabemos que la condesa de Castiglione no posaba con Ernst Mayer sino con Louis Pierson, y que sus fotografías permanecían ocultas al público, ${ }^{59}$ es probable

\footnotetext{
${ }^{52}$ Véase: “Anónimo, Retrato de la condesa de Guaqui con disfraz de música, ca. 1860, BNE, fondo fotográfico de la Col. Castellano, tomo 5, 17-LF/50-13v.2" y "Álbum de Señoritas y Correo de la Moda, 24/01/1855, p. 9".

${ }^{53}$ La Moda Elegante, 12/04/1863, p. 9

${ }^{54}$ Es el caso de la tienda "Nuestra Señora de París" que en 1861 anunciaba la venta, entre otros tantos productos franceses, de "albums para fotografías y fotografías artísticas": El Clamor público, 06/11/1861, p. 4.

${ }^{55}$ Léopold-Ernest (1817-1865) y Louis-Frédéric (1822-1913) abrieron un estudio de retrato por un mes en la Puerta del Sol 7 en junio de 1850. Véase el anuncio de su llegada: El clamor público, 24/05/1850, p. 4 citado en: GARCÍA FELGUERA, op. cit., 2014, p. 466. Ernest volvería a Madrid a finales de 1864 ( $L a$ Correspondencia de España, 14/12/1864 (edición de mañana), p. 3 citado en: ibídem, p. 475), al existir algunas tensiones entre éste y Louis Pierson: MCCAULEY, 1994, 12.

${ }^{56}$ Ernest Mayer regresó a París en otoño de 1865, Diario oficial de avisos 10/10/1865, p. 2 citado en: ibídem.

${ }^{57}$ Una práctica muy corriente para los fotógrafos, y especialmente empleada por Ernest Mayer en París:

MCCAULEY, op. cit., p. 94.

${ }^{58}$ La Esperanza, 03/02/1865, p. 2 citado en: GARCÍA FELGUERA, op. cit., 2014, p. 476.

${ }^{59}$ La condesa de Castiglione tenía mucha fama en España, y su nombre solía aparecer en los periódicos de la época. La primera referencia a la misma en la prensa española se ha localizado en diciembre de 1856 (Diario de Palma, 30/12/1856, p. 3). En marzo de 1857, se menciona que "la condesa de Castiglione
} 
que Mayer haya tenido conocimiento de su existencia y, en este sentido, no sorprendería la importación de algunas tipologías especialmente llamativas a Madrid, provocando la sustracción de las piezas. ${ }^{60}$

Disdéri también anunció su venida en septiembre de 1864, buscando "un jardín, una azotea ó una casa en que se pueda edificar una galería inmediatamente". ${ }^{1}$ A su llegada, se instalaría finalmente en el estudio de otro fotógrafo francés -el conde de Vernay- en la calle Pontejos $6 .{ }^{62}$ A la vuelta de éste en diciembre de $1864,{ }^{63}$ Disdéri se mudaría a otro local en la calle Príncipe 14 (cerca del estudio de Eusebio Juliá (1826-1895) situado en el número 27). ${ }^{64}$ En la prensa, en varias ocasiones se menciona el éxito del escaparate de Disdéri, ${ }^{65}$ y se entiende que numerosas mujeres pudieron extraer de allí nuevas ideas de posados: “¿Y no le ha sugerido á Vd. ninguna reflexión el contemplar reunidas en el corto espacio de una vara cuadrada tantas notabilidades europeas, desde los payasos del Circo de Price hasta el Emperador Luis, que es el que lleva hoy la batuta en el gran teatro del mundo?"66

Asimismo, el fotógrafo hizo gran uso de la prensa para promocionar su actividad (contamos más de 50 apariciones en menos de 3 años), ${ }^{67}$ algo que podría interpretarse tanto como una técnica comercial favorecida por el éxito de su estudio, o como una necesidad de optimizar un viaje que quizá no era del todo rentable. En vista de las numerosas interacciones de Disdéri con el público, por ejemplo durante sus ensayos con la luz eléctrica, ${ }^{6}$ nos decantaremos por la primera opción pues, como bien lo destaca Eusebio Blasco en El ángel del Hogar (revista femenina por excelencia), Disdéri era "el fotógrafo fashionable" del momento: "Mr. Disdéri, el fotógrafo fashionable, va á partir de Madrid muy pronto. Aprovechen la ocasión las niñas bonitas, y logren que cuando el

continúa en voga [sic] en la alta sociedad" y que "vestía un elegante traje de criada bretona, [llamando] como siempre, la atención por su gracia y jovial carácter" (Véase: La España, 31/3/1857, p. 1). Entre esta fecha y 1899, se menciona en treinta y tres ocasiones el nombre de la condesa de Castiglione, antes de que se anuncie su fallecimiento el 30/11/1899 (El Cantábrico, 30/11/1899, p. 3). Sin embargo, no existen pruebas de que las fotografías de la condesa se hayan difundido públicamente antes de su fallecimiento. Véase: APRAXINE y DEMANGE, 1999 y SOLOMON GODEAU, 2016 (1987). Es más, las noticias posteriores al mismo parecen contradecir esta teoría, pues hacen referencia al descubrimiento de "multitud de retratos de la bella dama, expléndidamente [sic] ataviada y atrevidamente descotada" (La Lucha, 07/05/1901, p. 2). Asimismo, es más que probable que la exposición de fotografías suyas en Madrid se hubiese mencionado, o incluso hubiese creado alguna conmoción social.

${ }^{60}$ El ladrón o uno de sus complices fue localizado unos días más tarde, sin que se conociera el motivo del robo o su identidad. Véase: La Esperanza, 06/02/1865, p. 4. Le damos las gracias a María de los Santos García Felguera por facilitarnos esta información.

${ }^{61}$ La Época, 13/09/1864, p. 4.

${ }^{62}$ El anuncio de su llegada se haría en: La Correspondencia de España, 20/09/1864, p. 4 citado en: GARCÍA FELGUERA, op. cit., 2014, p. 475, mientras que se anunció su instalación en el estudio del Conde de Vernay en el mismo periódico, 10 días más tarde: La Correspondencia de España, 30/09/1864, p. 2.

${ }^{63}$ La Época, 22/12/1864, p.3 citado en ibídem.

${ }^{64}$ El Pabellón nacional, 29/01/1865, p. 4.

${ }^{65}$ El gran interés generado por los escaparates se ve reflejado en: El Pabellón nacional, 29/1/1865, p. 4 y sobre todo en El Clamor público, 02/12/1860, p. 1, donde se describe el escaparate de fotografías de Disdéri en la Dalia Azul (librería especializada en venta de fotografías situada en la Carrera de San Jerónimo de Madrid)

${ }^{66}$ El Clamor público, 02/12/1860, p. 1.

${ }^{67}$ Las menciones a Disdéri empiezan en enero de 1860, pero es a partir de 1864 -cuando el fotógrafo abre un estudio en Madrid- que se intensifica su uso de la prensa como medio de comunicación comercial en España. El primer anuncio de Disdéri se publicó en agosto de 1864 (La Época, 12/08/1864, p. 4). Entre su llegada en septiembre de 1864 (La Época, 20/09/1864, p. 4 citado en: GARCÍA FELGUERA, op. cit., 2014, p. 475.) y su vuelta a París en 1867 (El Siglo ilustrado, 16/6/1867, p. 10) el fotógrafo publicó más de 40 anuncios. Para más información sobre las estrategias comerciales de Disderi, véase: MCCAULEY, op. cit., p. 84.

${ }^{68}$ La Época, 21/11/1864, p. 4. 
fotógrafo parisien presente en París su colección de bustos españoles, los franceses sientan deseos de visitar el país de las mujeres hermosas". ${ }^{69}$

El consejo de Eusebio Blasco parece haber sido seguido, puesto que se localizaron varios retratos de personalidades españolas en los inventarios del establecimiento parisino de Disdéri, que numerosas aristócratas visitaron. El Musée d'Orsay conserva por ejemplo ocho pruebas de la sesión realizada en 1860 por Lorenza Fernández de Villavicencio y del Corral, hija del duque de San Lorenzo, VIII condesa de Belmonte de Tajo y VII marquesa de Salar (1840-1921) (Figura 5). ${ }^{70}$

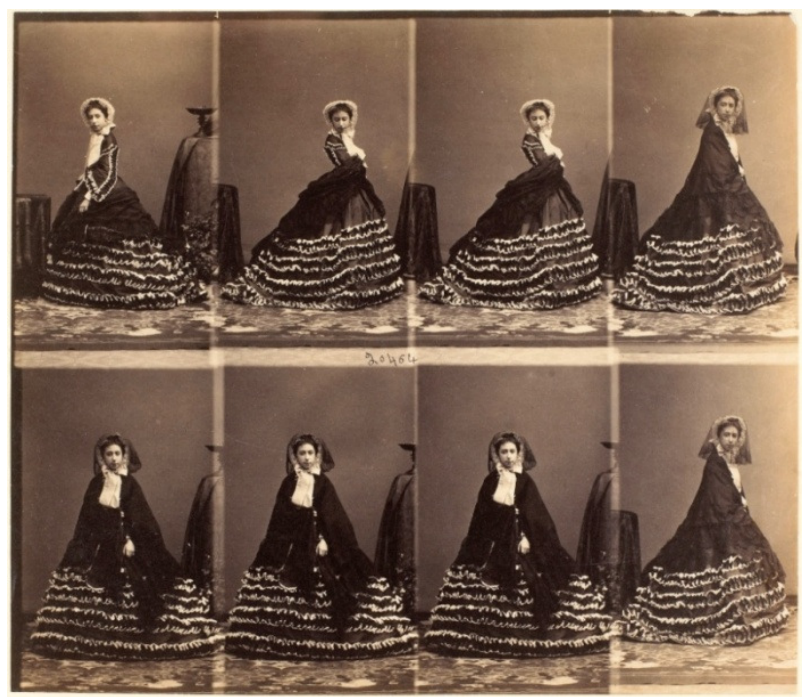

Figura 5: Disdéri, Lorenza Fernández de Villavicencio y del Corral, marquesa de Salar, de pie, en ocho poses, 1860, Musée d'Orsay, 17-632651 (photo @ Musée d'Orsay, Dist. RRMN-Grand Palais /

Patrice Schmidt).

La marquesa de Salar es un personaje sumamente interesante para entender el entusiasmo de la población femenina por la fotografía. Dieciséis retratos suyos (sacados durante diferentes sesiones y en los cuales se incluye en ocasiones a su hermana María Eulalia Fernández de Villavicencio y del Corral, marquesa de la Mesa de Asta (fl. 18441870), ${ }^{71}$ se conservan en la Biblioteca Nacional de España, y en la Fundación Lázaro Galdiano. ${ }^{72}$ Los retratos de Lorenza Fernández de Villavicencio, cuyos patrones son variados e imaginativos, demuestran el perfecto entendimiento que tenía de la fotografía como medio de expresión, pero también como un medio de comunicación. ${ }^{73}$

\section{De lo francés a lo castizo, y viceversa}

\footnotetext{
${ }^{69}$ Eusebio Blasco, El Ángel del hogar, 16/07/1865, p. 9, citado en: ALMARCHA NÚNEZ-HERRADOR et al., 2007, pp. 24-25.

70 Diccionario bibliográfico de la Real Academia de la Historia (en adelante DBe): http://dbe.rah.es/biografias/27634/lorenza-fernandez-de-villavicencio-y-corral [Consulta: 05/04/2020]

${ }^{71} \mathrm{BNE}$, fondo fotográfico de la Col. Castellano, tomo 3 (17-LF/48-41v.4); tomo 4 (17-LF/49-63.1); tomo 8 (17-LF/53-62.1) y tomo 11 (17-LF/56-187.4). María Eulalia Fernández de Villavicencio y del Corral también tenía un gran interés por el retrato fotográfico. En la BNE se conservan, además de los tres retratos con su hermana, unos doce retratos. Véase: BNE, fondo fotográfico de la Col. Castellano, tomo 2 (17$\mathrm{LF} / 47-1.6,22.8,46.7,53.6,57.5,57.8$ y 86.6); tomo 3 (17-LF/48-41v.5); tomo 11 (17-LF-147.3; 187.2 y 193.9) y tomo 18 (17-LF/63-15 y 16).

72 BNE, fondo fotográfico de la Col. Castellano, tomo 2 (17-LF/47-94); tomo 4 (17-LF/49-47v.5, 52.5 y 63.1); tomo 5 (17-LF/50-12v.8); tomo 8 (17-LF/53-6.8 y 62.1); tomo 11 (17-LF/56-187.4); tomo 16 (17LF/61-335.2) y tomo 18 (17-LF/63-145). Fundación Lázaro Galdiano, RAF.1296 y RB.21572-131.

${ }^{73}$ La consideración de la fotografía y de la representación como medio de expresión y de comunicación ha sido desarrollado en: YEN, op. cit., 2014, p. 116-170 y ONFRAY, op. cit., 2016, p. 524-525.
} 
La atracción de la marquesa de Salar por las formas parisinas es explicita en una buena mayoría de sus retratos. ${ }^{74}$ Sin embargo, tenía sus propios intereses representativos, por lo que adaptó dichos patrones a formas más castizas, entonces especialmente populares en España, dentro del marco de construcción nacional. En este sentido, Eugenia de Montijo (1826-1920), emperatriz de los franceses nacida en Granada, resultó ser el símbolo perfecto de la simbiosis entre los valores de modernidad franceses y la identidad tradicional española. La utilización de una indumentaria pintoresca durante sus visitas a Andalucía fue especialmente apreciada y difundida, ${ }^{75}$ algo que se reflejó a posteriori en los estudios fotográficos, y en particular en los retratos de la marquesa de Salar (Figura $6)$.
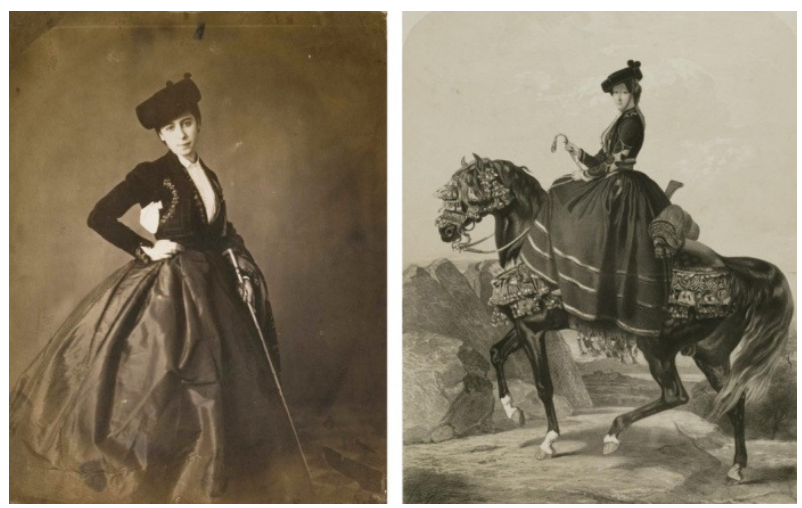

Figura 6: Comparación entre “Atribuido a José Martínez Sánchez, Retrato de la Marquesa de Salar, 1861, fondo fotográfico de la Colección castellano, tomo 18, 17-LF/63-145, BNE” y “Edouard Odier (litografía de Achille Giroux), Retrato de Eugenia de Montijo a caballo, ca. 1850, Museo Nacional del Romanticismo, CE5251”.

Sin embargo, más allá de la simple imitación de modelos, lo que puede observarse en ciertas imágenes de la marquesa de Salar se acercaría más bien a la apropiación y reinterpretación visual, pues adapta estas tipologías a sus propias necesidades particulares. Casada en 1859 con Fernando Pérez del Pulgar y Fernández de Córdoba (1833-1895) -descendiente de Hernán Pérez del Pulgar (1451-1531), héroe de las guerras de la reconquista de Granada $^{76}$ la aristócrata asume el rol de representación familiar asociado a su género y a su clase apareciendo, al igual que Eugenia de Montijo, vestida a la andaluza con una chaquetilla goyesca, una montera, y una fusta. Así, la marquesa

\footnotetext{
${ }^{74}$ La propia atracción de la marquesa por la representación queda patente con el retrato que de ella hizo Luis de Madrazo y Kuntz en 1856, actualmente conservada en la colección Duque de San Lorenzo y cuya fotografía se encuentra en el archivo moreno del Instituto del Patrimonio Cultural Español (en adelante IPCE). Véase: Luis de Madrazo y Kuntz, Retrato de mujer, 1856, IPCE, Casa Moreno, Archivo de Arte Español (1893-1953), Colección Duque de San Lorenzo, 06204_B, disponible en: http://www.mcu.es/fototeca_patrimonio/show_ficha.do?archivo=MORENO\&record=06204_B [consulta: 05/04/2020].

${ }^{75}$ Existen varias representaciones de Eugenia de Montijo vestida a la andaluza, en general representada en retratos ecuestres. Véase por ejemplo el cuadro de Manuel Barrón y Carrillo, Sevilla a mis pies, 1860, colección particular, reproducido en: PLAZA ORELLANA, 2009, p. 199, o Edouard Odier (litografía de Achille Giroux), Retrato de Eugenia de Montijo a caballo, ca. 1850, Museo Nacional del Romanticismo CE5251, publicado en este artículo (véase figura 6).

76 DBe: http://dbe.rah.es/biografias/27634/lorenza-fernandez-de-villavicencio-y-corral [Consulta: 05/04/2020]. Si nos fiamos de las anotaciones presentes en la parte trasera de la fotografía ("La Marquesa del Salar en 1861"), es muy probable que la retratada haya dado luz (o esté a punto de darla) ese mismo año a Fernando Pérez del Pulgar y Fernández de Villavicencio, nacido el 25 de julio de 1861. Véase: Retrato de la hija del duque de San Lorenzo, BNE, fondo fotográfico de la Col. Castellano, tomo 2, 17-LF/47094.1.
} 
empleó los mismos elementos codificados que la emperatriz, nacida igualmente en Granada, con el fin de ostentar el pasado heroico de su familia.

Otra representación de Lorenza Fernández de Villavicencio con el mismo atuendo también se halla en el fondo fotográfico de la Colección Castellano (Figura 7). Esta segunda imagen podría estar refeririendose a otro tipo de influencias, quizá relacionadas con las puestas en escena utilizadas, entre otras parisinas, por la condesa de Castiglione. ${ }^{77}$
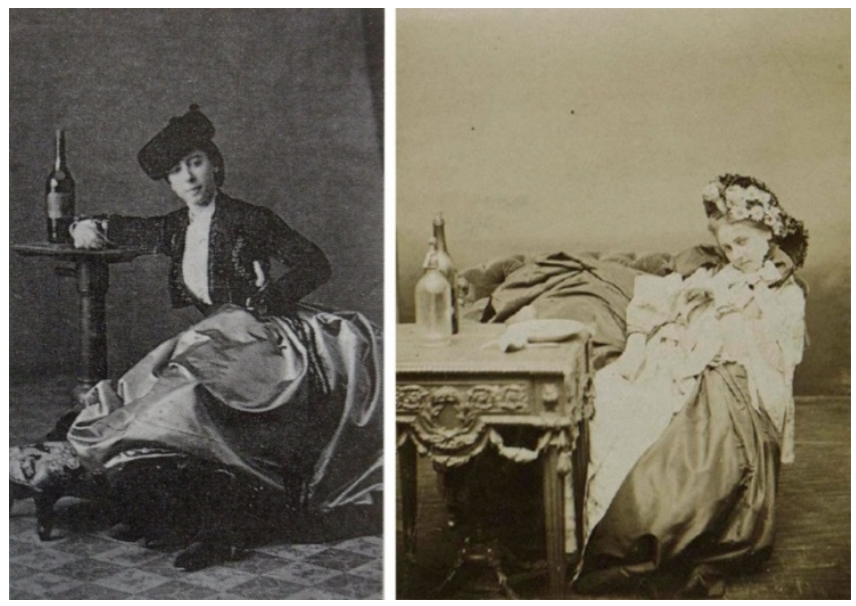

Figura 7: Comparación entre el Retrato de la Marquesa de Salar (atribuido a José Martínez Sánchez, 1861, fondo fotográfico de la Colección castellano, BNE) y un detalle de Midi-Minuit, retrato de la condesa de Castiglione (Pierre-Louis Pierson, 1861-1867), Metropolitan Museum of $\mathrm{Art}^{78}$.

Pero, por último, si bien las aristócratas españolas parecen haber importado modelos forasteros, adaptándolos o no a sus intereses personales, también llegaron a exportar otros tantos, que reivindicaban valores más cercanos a su propia identidad de clase. Así pudo haber ocurrido con la tipología de retrato con traje de caza y escopeta, de la que se conocen varias muestras, y cuyo origen podría situarse en el estudio de Ángel Alonso Martínez (1825-1868).

Dichas imágenes, además de referirse a la caza como afición elitista en la que en numerosas ocasiones las mujeres participaban, se inscriben en una tradición visual cuyos orígenes se remontan al siglo XVII (Figura 8). ${ }^{79}$

\footnotetext{
77 Vid supra notas 56 y 59. A pesar de que dudamos de que ninguna imagen de la Castiglione haya llegado a difundirse en los escaparates madrileños, la presencia de uno de los miembros del estudio de Mayer \& Pierson en Madrid podría llegar a explicar la difusión de esta tipología.

${ }^{78}$ Publicada en: APRAXINE y DEMANGE, op. cit., p. 126.

${ }^{79}$ Véase: Anónimo (escuela española), Retrato de mujer con traje de caza, Museo Cerralbo, 03808.
} 


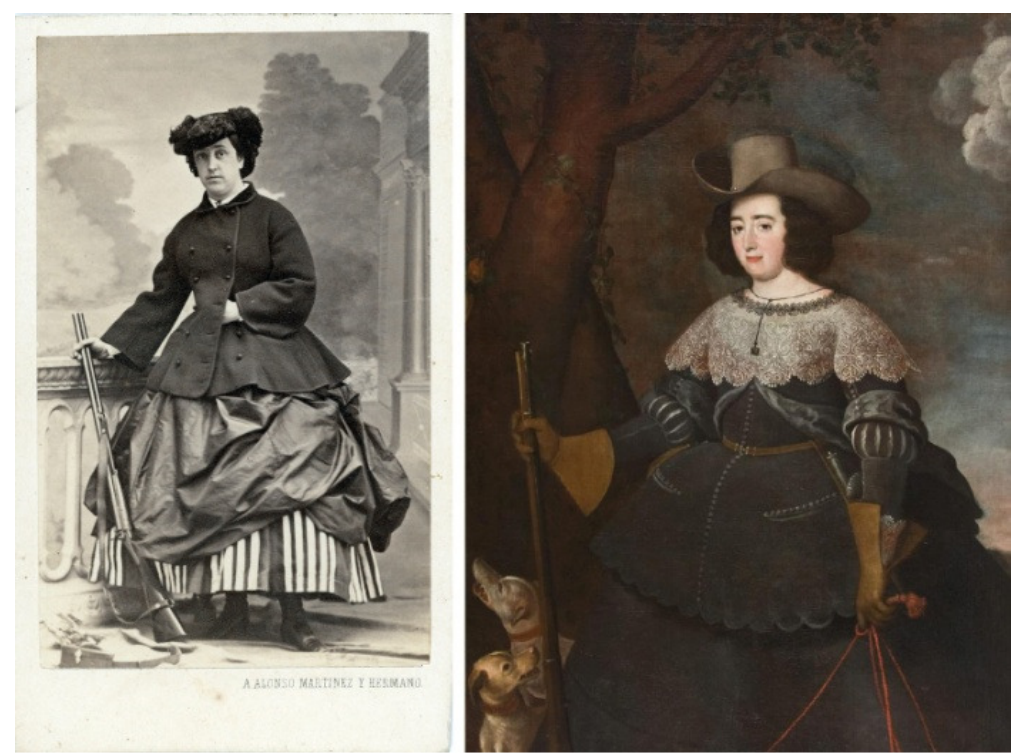

Figura 8: Comparación entre “A. Alonso Martínez y Hermano, Retrato de señora con escopeta, apoyada en una barandilla, ca. 1860, Archivo de Fotografía Histórica de Canarias, 35374, Colección José

A. Pérez Cruz” y “Anónimo (Escuela española), Retrato de mujer con traje de caza, ca. 1650, 03808, Museo Cerralbo".

Una tarjeta de este tipo, de la que una copia se localiza en el Musée d'Orsay y proviene del inventario del estudio de Disdéri, ${ }^{80}$ representa a María Álvarez de Toledo y Caro, XXII, condesa de Adernó (1847-1929) (Figura 9). Es de suponer que esta puesta en escena y la calidad del retrato hubiese llamado suficientemente la atención de Disdéri para llevarse la carte de visite a París ${ }^{81}$, y quizá hasta la haya incluido en el Álbum de celebridades españolas, cuya formación anunció en la prensa de la época. ${ }^{82}$

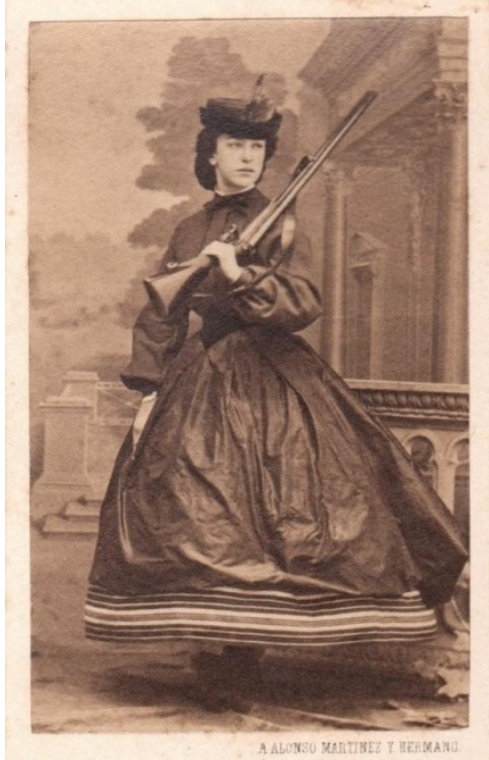

Figura 9: A. Alonso Martínez y hermano, María Álvarez de Toledo y Caro, XXII, condesa de Adernó, con traje de caza y escopeta, 1860, colección de la autora, copia de la imagen conservada en el Musée d'Orsay, PHO 19955329.

\footnotetext{
${ }^{80}$ Disdéri, Mlle Alvarez [sic] de Toledo, 1860, Musée d’Orsay, PHO 19955329.

${ }^{81}$ El ángulo de la toma y la dramatización de la pose denotan el interés pictórico de Ángel Alonso Martínez, que antes de ser fotógrafo fue pintor: OSSORIO Y BERNARD, 1868, pp. 22-23.

${ }^{82}$ A día de hoy no hemos localizado dicho álbum. La Correspondencia de España, 01/11/1864, p. 1 y 10/11/1864, p. 4, citado en: GARCÍA FELGUERA, op. cit., 2014, p. 475.
} 
Ello explicaría que María del Pilar Loreto Osorio y Gutiérrez de los Ríos, III duquesa de Fernán Núñez (1829-1921), también se haya retratado con una escopeta y un traje de caza, pero esta vez en el estudio del fotógrafo parisino (Figura 10). El parecido entre el estilo de Disdéri y Alonso Martínez, que ya se mencionaba en ciertos periódicos en $1860,{ }^{83}$ pudo haber servido de puente entre los estudios de ambos fotógrafos.

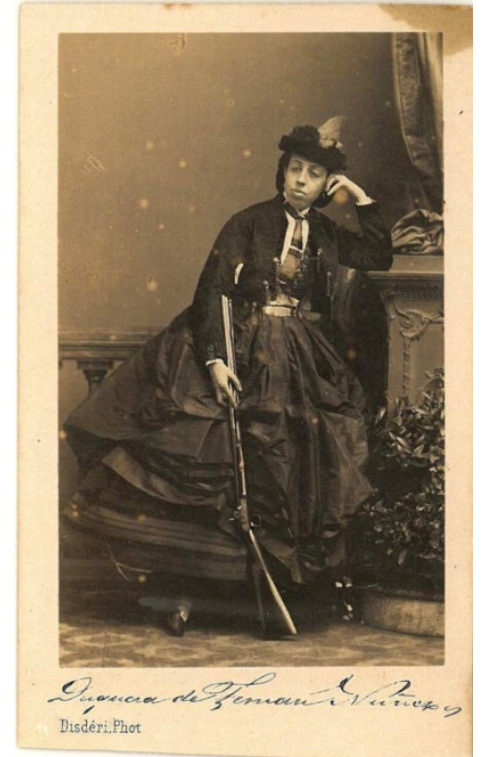

Figura 10: Disdéri (París), Retrato de la Duquesa de Fernán Nuñez con escopeta, ca.1860, colección de la autora.

Si bien sorprende que estas imágenes contradigan el valor de masculinidad que tradicionalmente se asocia a la caza, lo cierto es que a partir del siglo XVIII empezó a difundirse dicha práctica entre las mujeres de la élite europea, ${ }^{84}$ siempre respetando el ideal de feminidad en vigor. ${ }^{85}$ Esta expansión de la cacería a las mujeres favoreció la creación de nuevas indumentarias apropiadas ("falda corta, telas de colores naturales, botas resistentes y sombrero de plumas"), ${ }^{86}$ cuyo rastro se puede seguir en las revistas femeninas, ${ }^{87}$ y las cuales se exhibieron en los estudios fotográficos.

\section{Conclusiones}

El vínculo entre mujer y fotografía es heterogéneo, complejo, y crucial para entender la historia del medio. También lo son las relaciones entre Francia y España entre los siglos XVIII y XIX, así como sus consecuencias sobre la cultura de ambos países. Lejos de pretender tratar estos dos temas de forma exhaustiva, el propósito del presente artículo es más bien dar un primer esbozo de la influencia que pudieron tener ciertas personalidades y costumbres francesas sobre el desarrollo de la fotografía en España -

\footnotetext{
${ }^{83}$ Pedro Fernández indicaba en 1860: "Poned sus obras al lado de las del famoso Disdéri, de París, y convendréis en que algunas pueden sostener con las de aquel la competencia”. Véase: La Época, 28/01/1860, p. 3, citado en J. MARTÍ BAIGET, 27/09/2014.

${ }^{84}$ YEN, 2014, p. 248. Aun así, si las referencias a la caza fueron frecuentes en las revistas femeninas, pues durante los retiros al campo "se caza durante el día, se baila por la noche" (El Correo de la moda, 12/1852, p.11 (426), la mayoría de las menciones se refieren a la actividad como siendo un pasatiempo masculino.

${ }^{85}$ Ibídem, p. 251.

${ }^{86}$ BREVIK-ZENDER, 2015, p. 146. Eugenia de Montijo disponía por ejemplo de una cartuchera diseñada expresamente para estas ocasiones: PRADIÉ-OTTINGER, 2002, p. 168.

87 Se publicaban por ejemplo patrones para la realización de sus propios guantes, bufandas o chalecos de caza. Véase: La Moda Elegante, 31/03/1861, p. 6.
} 
bien sea como proceso técnico o como medio de expresión-, y cómo las mujeres se transformaron rápidamente en embajadoras de la misma en el país. ${ }^{88}$

De este modo, destacando la presencia de varias fotógrafas operando en el suelo español ya durante la década de los años 1840 , se ha demostrado que éstas tuvieron un cierto influjo sobre la implantación de la fotografía en el país. Asimismo, se ha comprobado que ellas favorecieron una paulatina feminización de la práctica, bien sea como profesional o como amateur.

Además, se ha visto cómo, mediante estrategias de representación muy relacionadas con la mímesis o el rechazo de algunas influencias francesas (adquiridas in situ o mediante la lectura de la prensa femenina), poco a poco las mujeres transformaron la cámara en la cómplice de sus necesidades expresivas.

La tensión entre lo francés y lo castizo, entre lo moderno y lo tradicional, típica del proceso de formación de las identidades nacionales durante la edad contemporánea, se ve perfectamente reflejada en numerosos retratos femeninos de la época, a su vez basados en el conjunto de la cultura visual.

Estas cartes de visite, que se exponían públicamente en los escaparates madrileños, o se intercambiaban en concurridas reuniones sociales, demuestran sin duda la importancia que podía cobrar la representación personal como marcador ideológico, y son una prueba más del papel que podía llegar a cobrar la mujer en una sociedad basada en un perpetuo culto a las apariencias.

\section{REFERENCIAS BIBLIOGRÁFICAS}

AGUSTÍN LACRUZ, María del Carmen y TOMÁS ESTEBAN, Sandra "Las primeras mujeres fotógrafas en Aragón: pioneras y modernas", Revista General de Información y Documentación, vol. 28 (2), 2018, pp. 621-658.

Álbum de Señoritas y Correo de la Moda, 24 de enero de 855, p. 9.

Álbum de Señoritas y Correo de la Moda, 16 de diciembre de 1856, p. 9.

ALMARCHA NÚNEZ-HERRADOR, Esther et al., "Evocación, historia y tarjetas postales entre repúblicas (1869-1939)", en CRESPO JIMÉNEZ, Lucía y VILLENA ESPINOSA, Rafael (dirs.), Fotografía y Patrimonio. II encuentro en Castilla la Mancha, Ciudad Real, Ediciones de la Universidad de Castilla-La Mancha, 2007, pp. 22-45.

APRAXINE, Pierre y DEMANGE, Xavier, La comtesse de Castiglione par elle-même, París, Réunion des Musées Nationaux, 1999.

ARTOLA GALLEGO, Miguel, Los afrancesados, Madrid, Alianza, 2008.

BLANCO, Alda, Escritoras virtuosas. Narradoras de la domesticidad en la España isabelina, Granada, Universidad de Granada, 2001.

BREVIK-ZENDER, Heidi, Fashioning Spaces: Mode and Modernity in Late-Nineteenth-Century Paris, Toronto, University of Toronto Press, Scholarly Publishing Division, 2015.

CANCER MATINERO, José Ramón, Retratistas fotógrafos en Valencia (1840-1900), Institució Alfons el Magnànim, Valencia, 2006.

\footnotetext{
${ }^{88}$ Aunque no hayamos podido aplicar esta teoría al estudio de las actrices francesas que tuvieron la ocasión de trabajar en Madrid, por ser un asunto que se merecería una investigación propia, conviene mencionar la influencia que tuvieron algunas de ellas -como Constance Nantier-Didiée (1831-1867), entre muchas otrassobre la difusión de formas de representación fotográficas y sobre la utilización de la cámara como agente de comunicación, ya en los años 1850. A este propósito, recomendamos los trabajos de Irene Mendoza Martín, aunque éstos se centren en los últimos años del siglo XIX y los primeros años del siglo XX, pues en ellos trasciende la importancia que tuvo la cultura visual -y en particular la fotografía- en las estrategias de autopromoción empleadas por ciertas actrices teatrales y, más adelante, fílmicas: MENDOZA MARTÍN, 2018, p. 213-236.
} 
DAGUERRE, Louis-Jacques-Mandé, "Daguerrotype (1838)", en BONNET, Manuel y MARIGNIER, jean-Louis (dirs.), Niépce. Correspondance y papiers, Maison Nicéphore Niepce, Saint-Loup de Varennes, 2003, vol.2, pp. 1098-1099.

DI BELLO, Patrizia, Women's Albums and Photography Victorian England: Ladies, Mothers and Flirts, Aldershot, Ashgate, 2007.

----- "Femme y photographies en Grande-Bretagne (1839-1870): de la marge à l'avant garde", POHLMANN (dir.), Qui a peur des femmes photographes? 1839-1945, París, Musée d'Orsay, 2015, pp. 64-107.

Diario oficial de avisos, 10 de octubre de 1865, p. 2.

Diario de Palma, 30 de diciembre de 1856, p. 3.

El Ángel del hogar, 16 de julio de 1865, p. 9.

El Cantábrico, 30 de noviembre de 1899, p. 3.

El Clamor público, 02 de diciembre de 1860, p. 1.

---- 06 de noviembre de 1861, p. 4.

El Eco del comercio, 26 de octubre de 1847, p. 4.

El Heraldo, 12 de agosto de 1842, p. 4.

---- 08 de noviembre de 1849 , p. 4.

El Imparcial, 10 de mayo de1843, p. 4.

El Pabellón nacional, 29 de enero de 1865, p. 4.

El Phoenix, 13 de abril de 1845, p. 4 (150).

El Siglo ilustrado, 16 de junio de 1867, p. 10.

El Correo de la moda, 12, 1852, p. 11 (426).

FOUCHIER, Arnauld de Prestige de la Photographie, vol. 1, París, Éditions EPA, 1977.

GALIFOT, Thomas, "La femme photographe n'existe pas encore positivement en France". Femmes, féminité y photographie dans le discours français au XIXème siècle y au début du XXème siècle.”, en POHLMANN, Ulrich (dir.), Qui a peur des femmes photographes? 18391945, París, Musée d'Orsay, 2015, pp. 35-49.

----- "La parentèle au risque de la photographie ? Amateures et professionnelles au XIXe siècle et au début du XXe siècle (France, Grande-Bretagne, États-Unis)", en VV.AA. Parent-elles, compagne de, fille de, sæur de... : les femmes artistes au risque de la parentèle, París, Aware, 2017, pp. 1-5, disponible en : https://awarewomenartists.com/publications/parentele-risquede-photographie-amateures-professionnelles-xixe-siecle-debut-xxe-siecle-france-grandebretagne-etats-unis/ [Consulta: 16/04/2020].

GARCÍA FELGUERA, María de los Santos, "Una pandilla de locas". Mujeres daguerrotipistas en Cataluña “, en: VV.AA., La mirada captiva, Fundación Mapfre, 2021, Barcelona (en prensa)."

---- "La versatilidad de los daguerrotipistas. Nuevos datos sobre los que trabajaron en Barcelona", en HERNÁNDEZ LATAS, José Antonio (dir.), I Jornadas sobre Investigación en Historia de la Fotografía. 1839-1939: Un siglo de fotografía, Zaragoza, Institución Fernando el Católico, 2017, pp. 51-58.

"El papel de París y los fotógrafos franceses en la fotografía española del siglo XIX", en SAZATORNIL RUIZ, Luis y F. JIMÉNO, Frédéric (dir.), El arte español entre Roma y París: siglos XVIII y XIX: intercambios artísticos y circulación de modelos, Madrid, Casa de Velázquez, 2014, pp. 451-476.

-- "Investigación sobre una fotógrafa que trabajó en España en el siglo XIX, la senora Ludovisi”, en VV.AA., Imatge i recerca, 10es Jornades Antoni Varés, Girona, Ajuntament de Girona, 2008, pp.1-5

"Los estudios de fotografía en la Barcelona de fin de siglo: Audouard y Napoleón", en TARRAUBELLA I MIRABET, Xavier (dir.) y GRAU I FERNÁNDEZ, Ramón (coord.), $X$ Congrés d'Història de Barcelona - Dilemes de la fi de segle, 1874-1901, Barcelona, Arxiu Històric de la Ciutat de Barcelona, Institut de Cultura, Ajuntament de Barcelona, 2007, pp. 169-184. 
“Anaïs Tiffon, Antonio Fernández y la compañía fotográfica "Napoleon", Locus Amoenus, vol. 8, 2005-2006, pp. 307-335.

GARÓFANO SÁNCHEZ, Rafael, Cádiz en la fotografía del siglo XIX, Cádiz, Unicaja, Obra Socio Cultural, D.L., 1993.

GÓNZALEZ PÉREZ, Antonio Jesús, La Mezquita de plata, Córdoba, Diputación de Córdoba, 2007.

HANNAVY, John, Encyclopedia of 19th Century Photography, Londres, Routledge, 2008.

HIGONNET, Anne, "Las mujeres y las imágenes. Apariencia, tiempo libre y subsistencia", en G. DUBY y M. PERROT (dirs.), Historia de las mujeres. Vol. 4. El siglo XIX, Madrid, Taurus, 2018 [1991], pp. 297-319.

HUDGINS, Nicole, The gender of photography, Londres, Bloomsbury Publishing PLC, 2020.

HUGUET CHANZÁ, José, Historia de la fotografía Valenciana, Valencia, Levante - El Mercantil Valenciano, 1990.

La Correspondencia de España, 20/09/1864, p. 4.

---- 30 de setiembre de 1864, p. 2.

---- $\quad 01$ de noviembre de 1864, p. 1.

---- 10 de noviembre de 1864, p. 4.

14 de diciembre de 1864 (edición de mañana), p. 3.

La Discusión, 04 de noviembre de 1865, p. 4.

La Época, 28 de enero de 1860, p. 3.

---- 12 de agosto de 1864, p. 4.

---- 13 de setiembre de 1864, p. 4.

---- $\quad 21$ de noviembre de 1864, p. 4.

---- 22 de diciembre de 1864, p. 3.

---- $\quad 31$ de marzo de 1857, p. 1.

---- $\quad 03$ de febrero de 1865, p. 2.

---- $\quad 06$ de febrero 1865, p. 4.

La Iberia, 01 de setiembre de 1865, p. 4.

La Lucha, 07 de mayo de 1901, p. 2.

La Moda Elegante, 31 de marzo de 1861, p. 6.

---- $\quad 12$ de abril de 1863, p. 9.

---- $\quad 13$ de diciembre de 1863, p. 5.

---- $\quad 31$ de julio de 1864 , p. 9.

---- 11 de marzo de 1866, pp. 7-8.

---- $\quad 06$ de mayo de 1866, p. 8.

La Mode Illustrée, 01 de enero de1866, p. 5.

La Violeta, 13 de marzo de 1864, p. 17.

\section{---- 20 de marzo de 1864 , p. 17. \\ 23 de julio de 1865 , p. 17.}

Le Moniteur de la Mode, $\mathrm{n}^{\circ}$ 1, de abril de 1855, p. 2 bis.

MARTÍ BAIGET, Jep, "El camí cap a 1849: l'any en el que "Franck de Voyennes" va decidir passar uns dies a Barcelona, 08/06/2018, disponible en: https://lalbumdeljep.wordpress.com/2018/06/08/el-cami-cap-a-1849-lany-en-el-quefranck-de-voyennes-va-decidir-passar-uns-dies-a-barcelona/\# ftn2 [Consulta: 25/03/2020].

---- "El recorregut per Espanya i Portugal de la daguerreotipista Trachsler Fritz, de Zuric.

(1843-1845)", 2020, https://lalbumdeljep.wordpress.com (en prensa).

---- "Notes sobre la "carte-de-visite". Arribada i popularització a Barcelona i Madrid (18541862)", 27/09/2014, disponible en: https://lalbumdeljep.wordpress.com/2015/04/17/elminiaturista-i-fotograf-pedro-martinez-de-hebert-1a-part [Consulta: 08/04/2020].

MARTÍN-VALDEPEÑAS, Elisa, "Mis señoras traidoras. Las afrancesadas, una historia olvidada.", Revista HMiC, núm. VIII (2010), pp. 79-108. 
MCCAULEY, Elizabeth Anne, A. A. E. Disderi and the Carte de Visite Portrait Photograph, New Haven, Yale University Press, 1985.

“- "Arago, l'invention de la photographie y le politique", Études photographiques, vol. 2, 1997, pp. 1-24.

MENDOZA MARTÍN, Irene, "Las glorias del espectáculo. Actrices y celebridad en el primer tercio del siglo XX español", Ayer. Revista de historia contemporánea. Dossier: género y nación en la España contemporánea, 2018, p. 213-236.

MERCADER RIBA, Juan, José Bonaparte rey de España (1808-1813). Historia externa del reinado, Instituto Jerónimo Zurita - Consejo Superior de Investigaciones Científicas, 1971.

Ministère de l'agriculture y du commerce, Catalogue des brevets d'invention, d'importation y de perfectionnement. Dressé par ordre du Ministre de l'agriculture y du commerce (de l'intérieur, de l'agriculture y du commerce; de l'agriculture, du commerce y des travaux publics ; etc), París, Imprimerie y librairie de Mme Ve Bouchard-Huzard, 1854.

ONFRAY, Stéphany "La imagen de la mujer a través de la fotografía en el Madrid decimonónico: el ejemplo de la Colección Castellano de la Biblioteca Nacional de España.", en VV.AA., El legado hispánico. Manifestaciones culturales y sus protagonistas, vol. 1, León, Universidad de León, 2016, pp. 515-534.

- "Ellas: de modelo a fotógrafa. La mujer como impulsora de nuevas formas retratísticas en los estudios fotográficos madrileños (1860-1880)", Área Abierta. Monográfico: Tras la cámara. Estudios sobre mujeres fotógrafas, vol. 18 (1) (2018), pp. 13-37.

"Mujeres fotógrafas en el siglo XIX español: de lo profesional a lo doméstico", Fotografía [Femenino; plural]. Visiones, ensayos y otros escritos sobre mujeres fotógrafas, Madrid, Editorial Fragua, 2019, pp. 17-40.

OSSORIO Y BERNARD, Manuel, Galería biográfica de artistas españoles del siglo XIX, vol. 1, Madrid, Madrid Imprenta de Ramón Moreno, 1868.

PLAZA ORELLANA, Rocío, Historia de la moda en España. El vestido femenino entre 1750 y 1850, Córdoba, Editorial Almuzara, 2009.

PRADIÉ-OTTINGER, Bénédicte, L'art y la chasse: histoire culturelle y artistique de la chasse, Waterloo, La Renaissance du Livre, 2002.

Revista de Bellas Artes, 27/10/1866, p. 6.

SOLOMON-GODEAU, Abigail, "Les jambes de la comptesse", Chair à canons : Photographie, discours, féminisme, París, Textuel, 2016 (1987), p. 163-207.

VEGA DE LA ROSA, Carmelo, Fotografía en España (1839-2015). Historia, tendencias, estéticas, Madrid, Cátedra, 2017.

VELASCO MOLPECERES, Ana María, Moda y prensa femenina en España (siglo XIX), Madrid, Ediciones 19, 2016.

---- "La lectura como herramienta de inclusión social: mujeres y prensa en la España Isabelina (1833-1868)", en CANTARERO DE SALAZAR et al. (dirs), Jóvenes plumas del hispanismo: nuevos retos y enfoques de la investigación filológica, Madrid, Ediciones Complutense, 2018, pp. $97-114$

----- "La moda en los medios de comunicación: de la prensa femenina tradicional a la política y los/as influencers", Revista Prisma Social, 24 (2019), pp. 153-185, disponible en: https://revistaprismasocial.es/article/view/2845/2980 [Consulta: 22/04/2020].

VV.AA., El mundo al revés. El calotipo en España, Navarra, Museo Universidad de Navarra, 2015.

YEN, Ya-Lei, Clothing Middle-Class Women: Dress, Gender and Identity Mid-Victorian England c. 1851-1875, Royal Holloway, University of London, 2014. 